\title{
Mechanism of Insulin-resistant
}

\section{Glucose Transport Activity in the Enlarged Adipose Cell of the Aged, Obese Rat}

\author{
RELATIVE DEPLETION OF INTRACELLULAR GLUCOSE \\ TRANSPORT SYSTEMS
}

\author{
Paul J. Hissin, James E. Foley, Lawrence J. Wardzala, Eddy Karnieli, \\ Ian A. Simpson, Lester B. Salans, and Samuel W. Cushman, Cellular \\ Metabolism and Obesity Section, National Institute of Arthritis, Diabetes, \\ and Digestive and Kidney Diseases, National Institutes of Health, \\ Bethesda, Maryland 20205
}

\begin{abstract}
A B S T R A C T The effects of increasing cell size on glucose transport activity and metabolism and on the concentrations of glucose transport systems in both the plasma and low density microsomal membranes in isolated adipose cells from the aging rat model of obesity have been examined. Glucose transport activity was assessed by measuring $\mathrm{L}$-arabinose transport and the concentration of glucose transport systems estimated by measuring specific D-glucose-inhibitable cytochalasin B-binding. Basal glucose transport activity increases from 0.3 to $1.4 \mathrm{fmol} / \mathrm{cell} / \mathrm{min}$ with a 10 -fold increase in cell size, but remains constant per unit cellular surface area and is accompanied by a constant 5 pmol of glucose transport systems/mg of membrane protein in the plasma membrane fraction. Maximally insulin-stimulated glucose transport activity, on the other hand, remains constant at $2.3 \mathrm{fmol} /$ cell per min
\end{abstract}

Preliminary reports of this work were presented in part at the 1980 Annual Meeting of the American Diabetes Association in abstract form, and the Third International Congress on Obesity, Rome, 1980. Portions of this work were carried out as part of thesis research in the Physiology (by J. E. Foley) and Biochemistry (by L. J. Wardzala) Graduate Programs, Dartmouth College.

Dr. Hissin's present address is Department of Chemistry, Mount Sinai Hospital, New York, NY 10029. Dr. Foley's present address is Phoenix Clinical Research Section, National Institute of Arthritis, Diabetes, and Digestive and Kidney Diseases, National Institutes of Health, Phoenix, AZ 85016. Dr. Karnieli's present address is Metabolic Unit, Endocrine Institute, Rambam Medical Center, Haifa, Israel.

Received for publication $22 \mathrm{May} 1982$ and in revised form 15 June 1982. with increasing cell size, but markedly decreases per unit cellular surface area and is accompanied by a decrease from $30 \mathrm{pmol}$ of glucose transport systems/ mg of plasma membrane protein to the basal level. These diminished effects of insulin on glucose transport activity and the number of glucose transport systems in the plasma membrane fraction in enlarged cells are paralleled by an $80 \%$ decrease in the basal number of glucose transport systems/mg of membrane protein in the low density microsomal membrane fraction, the source of those glucose transport systems appearing in the plasma membrane in response to insulin. The effects of cell size on the metabolism of a low concentration of $\left[1-{ }^{14} \mathrm{C}\right]$ glucose $(0.56 \mathrm{mM})$ directly parallel those on glucose transport activity and the concentration of glucose transport systems in the plasma membrane fraction, and are not associated with significant alterations in the cell's sensitivity to insulin. Thus, adipose cellular enlargement is accompanied by the development of a marked "insulin resistance" at the glucose transport level, which may be the consequence of a relative depletion of glucose transport systems in the intracellular pool.

\section{INTRODUCTION}

Alterations in insulin's ability to influence glucose metabolism in the enlarging adipose cell have been observed both during normal growth and in obesity (1-6). Using the aging rat model of obesity, studies from several laboratories have shown that cellular en- 
largement may be accompanied by changes in insulinreceptor interaction, glucose transport activity, and glucose metabolism (7-18). Early reports suggested that insulin binding may either decrease or remain unchanged with increasing cell size (7-11). More recently, studies by Foley et al. (12), and in this laboratory (13), have demonstrated that insulin binding at physiological insulin concentrations actually increases per cell and remains roughly constant per unit cellular surface area. Thus, in the aging rat, alterations in insulin binding probably contribute little, if any, to the progressively altered metabolic response of enlarging cells to insulin.

In small rat adipose cells under physiological conditions, insulin regulates glucose metabolism primarily at the level of glucose transport $(19,20)$. However, whereas early reports suggested that basal and insulinstimulated glucose transport may either increase or remain unchanged with increasing cell size $(10,14-$ 16), additional reports have suggested that the impaired ability of insulin to influence glucose metabolism in the enlarged cell primarily reflects a reduction in the cell's capacity to utilize glucose and a dissociation of glucose metabolism from transport (10, 15-18). Nevertheless, at sufficiently low glucose concentrations, glucose utilization does parallel glucose transport activity, and the impaired metabolic response to insulin under these conditions can be directly attributed to a diminished glucose transport response (12).

Recent studies in this laboratory (21-23), and independent studies by Suzuki and Kono (24) and Kono et al. (25), have shown that $(a)$ insulin stimulates glucose transport in the isolated rat adipose cell primarily by increasing the concentration of the functional glucose transport systems in the plasma membrane, and (b) this process occurs through a rapid, reversible, and insulin concentration-dependent translocation of glucose transport systems from a large, membrane-associated intracellular pool to the plasma membrane. The present investigations were undertaken to examine (a) the effects of adipose cellular enlargement on basal and insulin-stimulated glucose transport activity in isolated intact adipose cells, $(b)$ the concentration of glucose transport systems in purified plasma membranes prepared from these cells of increasing size, and $(c)$ the potential role of the intracellular pool of glucose transport systems in alterations in the glucose transport response to insulin in the aging rat model of obesity.

\section{METHODS}

Animals. Male rats (CD strain, Charles River Breeding Laboratories, Inc., Wilmington, MA) were fed (Purina Rat Chow, Ralston Purina Company, St. Louis, MO) ad lib. for a minimum of $7 \mathrm{~d}$ before study. All animals were closely matched in weight within each experiment and killed by cervical dislocation and decapitation between 9 and $11 \mathrm{AM}$.
Experimental design. Four series of experiments were undertaken. In the first and second series, glucose transport activity and metabolism, respectively, were studied as functions of increasing insulin concentration in epididymal adipose cells of widely different size obtained from rats ranging in body weight from 150 to $600 \mathrm{~g}$. On occasion, glucose transport activity and metabolism were studied in separate samples of cells from the same cell preparation. In the third series of experiments, the concentration of glucose transport systems was assessed in the purified plasma membranes of basal and maximally insulin-stimulated cells obtained from rats ranging from 95 to $750 \mathrm{~g}$ in body weight. In the fourth series, the concentrations of glucose transport systems were assessed in the plasma, high density microsomal, and low density microsomal membrane fractions of basal and maximally insulin-stimulated small and large cells obtained from rats of $180-$ and $850-\mathrm{g}$ body weight, respectively. In each of these latter experiments, glucose transport activity was monitored in the intact cells before homogenization.

Preparation of isolated adipose cells and measurement of adipose cell size. For each experiment, a group of animals was killed, the epididymal fat pads were removed, and isolated adipose cells were prepared by the method described by Rodbell (26) and modified by Cushman (27). All incubations were carried out in Krebs-Ringer-bicarbonate (KRB) ${ }^{1}$ buffer, or in KRB buffer reduced to $10 \mathrm{mM} \mathrm{HCO}_{3}^{-}$and supplemented with $30 \mathrm{mM}$ Hepes (Sigma Chemical Co., St. Louis, MO), $\mathrm{pH} 7.4,37^{\circ} \mathrm{C}$, containing untreated bovine serum albumin (BSA) (Bovine Serum Albumin Powder, Fraction V, Reheis Chemical Co., Kankakee, IL) and glucose (Dextrose, National Bureau of Standards, Washington, DC) as appropriate. Due to the varying nature of the experimental protocols and the varying size and number of cells available from animals of different body weight, the number of rats per experiment was adjusted so that the volume occupied by cells during incubation was maintained at a roughly constant proportion of the total incubation volume. Adipose cell size was then determined in each preparation of cells by using the osmic acid fixation, Coulter Electronic Counter method (method III) described by Hirsch and Gallian (28) for intact tissue fragments, and modified for isolated cell suspensions by Cushman and Salans (29).

Measurement of glucose transport activity. Glucose transport activity was assessed by the L-arabinose uptake method described by Foley et al. $(30,31)$. After isolation, adipose cells were equally distributed among 5-ml plastic vials prepared in advance such that the final incubation volume would be $400 \mu$ l of KRB buffer containing isolated cells, $10 \mathrm{mg}$ untreated $\mathrm{BSA} / \mathrm{ml}$, and $0-1,000 \mu \mathrm{U}$ insulin $/ \mathrm{ml}$ (crystalline porcine $\mathrm{Zn}$ insulin, courtesy of Dr. Ronald E. Chance, Eli Lilly \& Co., Indianapolis, IN). The final cell concentration varied from 200 to $1,400 \times 10^{3}$ cells $/ \mathrm{ml}$. After $30 \mathrm{~min}$ of preincubation at $37^{\circ} \mathrm{C}$ under an atmosphere of $95 \% \mathrm{O}_{2}$ and $5 \% \mathrm{CO}_{2}, 50 \mu$ l of KRB buffer containing L- $\left[1-{ }^{14} \mathrm{C}\right]$ arabinose and L- $\left[1-{ }^{-3} \mathrm{H}\right]$ glucose (New England Nuclear, Boston, MA, and Calbiochem, La Jolla, CA) was added to the cells such that their final concentrations would be $1.0 \mathrm{mM}(250 \mu \mathrm{Ci} / \mathrm{mmol}$ and $2.5 \mathrm{mCi} / \mathrm{mmol}$, respectively). The cells were then incubated for 0.75 to $2.75 \mathrm{~min}$. Uptake was rapidly stopped by the subsequent addition of $20 \mu \mathrm{l}$ of a $10-\mathrm{mM}$ solution of cytochalasin B (Aldrich Chemical Co., Inc., Milwaukee, WI) in $95 \%$ ethyl alcohol. $200-\mu$ l samples of cells were then sep-

\footnotetext{
${ }^{1}$ Abbreviations used in this paper: BSA, bovine serum albumin; KRB, Krebs-Ringer-bicarbonate.
} 
arated from incubation medium by centrifugation through oil (32), and the radioactivity associated with the cells was counted. The rate of transport was calculated from these uptake values and the uptake values observed at zero time and at equilibrium, assuming an exponential uptake function.

Measurement of glucose metabolism. After isolation, adipose cells were equally distributed among $20-\mathrm{ml}$ plastic incubation vials prepared in advance such that the final incubation volume would be $1.5 \mathrm{ml}$ of KRB buffer containing isolated cells, $30 \mathrm{mg} \mathrm{BSA} / \mathrm{ml}, 0-1,000 \mu \mathrm{U}$ insulin $/ \mathrm{ml}$, and $0.56 \mathrm{mM}$ glucose at a specific activity of roughly $150 \mu \mathrm{Ci}$ $\left[1-{ }^{14} \mathrm{C}\right]$ glucose $/ \mathrm{mmol}$ (New England Nuclear). The final cell concentration varied from 130 to $610 \times 10^{3}$ cells $/ \mathrm{ml}$. After $60 \mathrm{~min}$ of incubation at $37^{\circ} \mathrm{C}$, under an atmosphere of $95 \%$ $\mathrm{O}_{2}$ and $5 \% \mathrm{CO}_{2}$, the ${ }^{14} \mathrm{C}$-activities in $\mathrm{CO}_{2}$, and triglyceride glycerol and fatty acids were measured as previously described (33). "Total" glucose utilization is defined here as the sum of the ${ }^{14} \mathrm{C}$-activities of the 1-carbon atom of glucose incorporated into $\mathrm{CO}_{2}$, and triglyceride glycerol and fatty acids.

Preparation of membrane fractions and determination of the number of glucose transport systems. Purified plasma membranes alone (third series of experiments) or plasma, high density microsomal, and low density microsomal membrane fractions (fourth series of experiments) were prepared by differential ultracentrifugation $(23,34)$. After isolation, adipose cells were equally distributed among $20-\mathrm{ml}$ (third series of experiments) or $950-\mathrm{ml}$ (fourth series of experiments) plastic incubation vials prepared in advance such that the final incubation volume would be 12 or $36 \mathrm{ml}$, respectively, of KRB-Hepes buffer containing isolated cells, $10 \mathrm{mg} \mathrm{BSA} / \mathrm{ml}$, and 0 or $1,000 \mu \mathrm{U}$ insulin $/ \mathrm{ml}$.

After $30 \mathrm{~min}$ of incubation at $37^{\circ} \mathrm{C}$, the incubated adipose cells were washed and homogenized in a buffer containing $20 \mathrm{mM}$ Tris- $\mathrm{HCl}, 1 \mathrm{mM}$ EDTA, and $255 \mathrm{mM}$ sucrose, $\mathrm{pH}$ 7.4; each homogenate was centrifuged at $16,000 g_{\max }$ (maximum gravity) for $15 \mathrm{~min}$. The pellet was then washed and resuspended and the resuspended membranes were centrifuged at $101,000 g_{\max }$ for $60 \mathrm{~min}$ on a discontinuous $1.12 \mathrm{M}$ sucrose gradient in $20 \mathrm{mM}$ Tris- $\mathrm{HCl}, 1 \mathrm{mM}$ EDTA, pH 7.4. The layer of plasma membranes formed on the gradient was removed, and the purified plasma membranes were washed and resuspended to a final concentration of $2-4 \mathrm{mg}$ of protein $/ \mathrm{ml}$. The initial supernatant (fourth series of experiments only) was then centrifuged at $48,000 \mathrm{~g}_{\max }$ for $15 \mathrm{~min}$, the supernatant was recentrifuged at $210,000 \mathrm{~g}_{\max }$ for $75 \mathrm{~min}$, and both pellets were washed and resuspended to final concentrations of 1-2 mg of protein $/ \mathrm{ml}$. Equilibrium D-glucoseinhibitable cytochalasin B-binding to each membrane fraction was then measured and the concentrations of D-glucoseinhibitable binding sites were calculated $(21,22,35)$.

The reproducibility of the fractionation procedure was assessed by measuring the specific activities of the following marker enzyme activities in various combinations: (a) $5^{\prime}$-nucleotidase and isoproterenol-stimulated adenylate cyclase by the methods described by Avruch and Hoelzl Wallach (36) and Salomon et al. (37), respectively; $(b)$ rotenone-insensitive NADH-cytochrome $c$ reductase and glucose-6-phosphate phosphatase by the methods described by Dallner et al. (38) and Nordlie and Jorgenson (39), respectively; and (c) UDPgalactose: $\boldsymbol{N}$-acetylglucosamine galactosyltransferase by the method described by Fleisher (40). Protein was determined by the method described by Lowry et al. (41) and modified by Peterson (42), using crystalline BSA (Sigma Chemical Co.) as the standard.

Calculations. Glucose transport activity and metabolism have been expressed per cell and per unit cellular surface area, assuming a total lipid density of $0.9 \mathrm{~g} / \mathrm{ml}$ in converting adipose cell size to volume and a spherical geometry in converting cell volume to surface area. The concentration of glucose transport systems in each membrane fraction has been expressed per milligram of membrane protein. All calculations were carried out on the Dartmouth Time-Sharing System (DTSS, Hanover, NH) computer facilities. Because the relationships between cellular function and cell size were often nonlinear (see Figs. 1-3), simple linear regression tests of statistical significance were carried out only where deemed appropriate by inspection. Where curvilinear relationships were clearly observed, curves have been drawn by inspection for illustrative purposes only. A $t$ test of statistical significance was employed wherever differences between small and large cells were examined directly (see Fig. 4 , and Tables I and II). Differences were accepted as statistically significant at the $P \leq 0.05$ level.

\section{RESULTS}

Glucose transport activity and metabolism per cell. Insulin concentration-dependent glucose transport activity (first series of experiments) and metabolism (second series of experiments) in isolated adipose cells of increasing size are illustrated in Figs. 1 and 2. The latter has specifically been examined only at a low extracellular glucose concentration $(0.56 \mathrm{mM})$ where transport is thought to represent the rate limiting step (18-20).

Increasing insulin concentrations progressively enhance both glucose transport activity and metabolism, regardless of adipose cell size (Fig. $1, \mathrm{~A}$ and $\mathrm{B}$, respectively). Responses are detectable at insulin concentrations as low as $2.5-5 \mu \mathrm{U} / \mathrm{ml}$, and half-maximal and maximal responses are observed at 10-20 and 50$100 \mu \mathrm{U} / \mathrm{ml}$, respectively. Increasing cell size is, however, associated with significantly increasing basal rates of both glucose transport activity and metabolism (Fig. 2, A and B, respectively). Indeed, at the low extracellular glucose concentration examined here, the increase in basal glucose metabolism closely parallels that in glucose transport activity. In the presence of a maximally stimulating concentration of insulin (100 $\mu \mathrm{U} / \mathrm{ml}$ ), however, glucose transport activity remains unchanged, whereas metabolism gradually decreases. The incremental stimulation of glucose transport activity by insulin tends, therefore, to decrease gradually, whereas the incremental stimulation of metabolism decreases more rapidly.

Glucose transport activity and metabolism per unit cellular surface area. Figs. $1 \mathrm{C}$ and $2 \mathrm{C}$, and $1 \mathrm{D}$ and $2 \mathrm{D}$ illustrate again the relationships between glucose transport activity and metabolism, respectively, and increasing adipose cell size when these activities are expressed per unit cellular surface area. In small cells with increasing insulin concentrations up to $1,000 \mu \mathrm{U} /$ $\mathrm{ml}$ and in large cells in the presence of very low insulin 


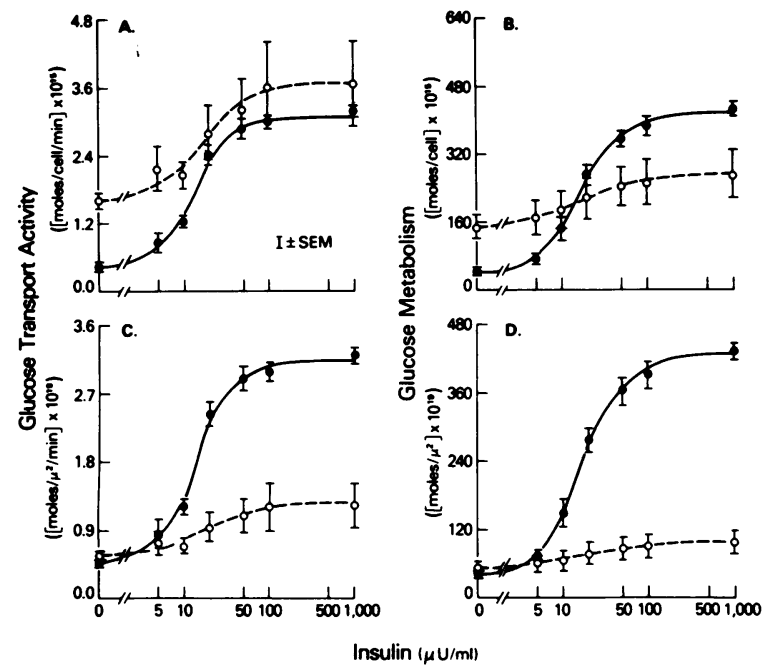

Figure 1 Insulin concentration-dependent L-arabinose transport and $\left[1{ }^{14} \mathrm{C}\right]$ glucose metabolism (sum of ${ }^{14} \mathrm{CO}_{2}$ and $\left[{ }^{14} \mathrm{C}\right]$ triglyceride production) per cell (A and $B$ ) and per unit cellular surface area $(C$ and $D)$ in small $(O)$ and large $(O)$ adipose cells (mean cell sizes of 0.083 and $0.408 \mu \mathrm{g}$ lipid/ cell, respectively). Isolated cells $\left(420-1,380 \times 10^{3}\right.$ cells $\left./ \mathrm{ml}\right)$ were prepared from the epididymal fat pads of groups of 200 - and $620-\mathrm{g}$ rats, preincubated for $30 \mathrm{~min}$ at $37^{\circ} \mathrm{C}$ in 0.40 $\mathrm{ml} \mathrm{KRB}$ buffer containing $10 \mathrm{mg} \mathrm{BSA} / \mathrm{ml}$ and $0-1,000 \mu \mathrm{U}$ insulin $/ \mathrm{ml}$, and incubated for $0.75-2.75 \mathrm{~min}$ in the presence of $1.0 \mathrm{mM} \mathrm{L}-\left[1-{ }^{14} \mathrm{C}\right]$ arabinose $(250 \mu \mathrm{Ci} / \mathrm{mmol})$ and $\mathrm{L}-[1-$ $\left.{ }^{3} \mathrm{H}\right]$ glucose $(2.5 \mathrm{mCi} / \mathrm{mmol})$. Additional isolated cells $(140-$ $290 \times 10^{3}$ cells $/ \mathrm{ml}$ ) were incubated in separate, but simultaneous, experiments for $60 \mathrm{~min}$ at $37^{\circ} \mathrm{C}$ in $1.5 \mathrm{ml} \mathrm{KRB}$ buffer containing $30 \mathrm{mg} \mathrm{BSA} / \mathrm{ml}, 0.56 \mathrm{mM}\left[1-{ }^{14} \mathrm{C}\right]$ glucose $(150 \mu \mathrm{Ci} / \mathrm{mmol})$, and $0-1,000 \mu \mathrm{U}$ insulin $/ \mathrm{ml}$. Results are the means \pm SEM of the individual mean values obtained from triplicate samples in each of the three small and three large cell preparations studied.

concentrations, glucose transport activity and metabolism closely parallel each other (Figs. 1, C and D, respectively). However, at higher insulin concentrations, transport is less diminished than metabolism in large cells relative to small cells. Differences in the concentrations of insulin producing half-maximal responses, a measure of the cell's "sensitivity" to hormone, are not demonstrable either between transport and metabolism or between small and large cells. Over the entire range of cell sizes examined here, both basal glucose transport activity and metabolism tend to decline slightly and in parallel with increasing cell size, but these decreases are not significant (Fig. 2, C and $D$, respectively). In the presence of a maximally stimulating concentration of insulin, however, glucose transport activity and metabolism both decrease markedly with cellular enlargement, although the reduction in glucose metabolism is somewhat greater than that in transport.
Concentration of glucose transport systems in the plasma membrane fraction. The concentrations of glucose transport systems in the plasma membrane fraction of isolated rat adipose cells of increasing cell size (third series of experiments) are illustrated in Fig. 3. Increasing cell size is accompanied by an unchanging number of glucose transport systems/milligram of membrane protein when purified plasma membranes are prepared from basal cells, but a markedly decreasing number/milligram of membrane protein when this membrane fraction is prepared from maximally insulin-stimulated cells. Furthermore, regardless of cell size, the number of glucose transport systems/milligram of plasma membrane protein closely parallels glucose transport activity in the intact cell when the latter is expressed per unit cellular surface area (Fig. $2 \mathrm{C}$ ).

Subcellular distribution of glucose transport systems. The distributions of glucose transport systems among the plasma, high density microsomal, and low density microsomal membrane fractions of isolated

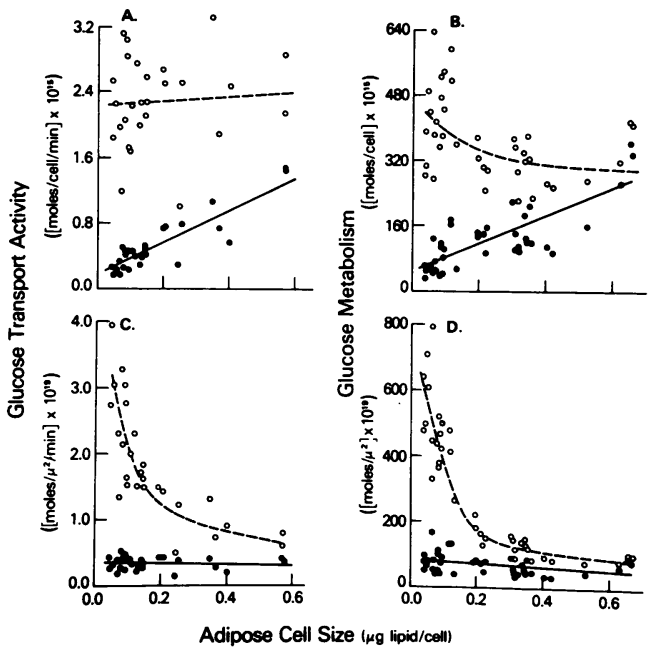

FIGURE 2 Relationship between basal (O) and insulin-stimulated $(O)$ L-arabinose transport and $\left[1-{ }^{14} \mathrm{C}\right]$ glucose metabolism (sum of ${ }^{14} \mathrm{CO}_{2}$ and $\left[{ }^{14} \mathrm{C}\right]$ triglyceride production) per cell ( $A$ and $B$ ) and per unit cellular surface area (C and D), and adipose cell size. $A$ and $C$ : isolated cells (200-1,100 $\times 10^{3}$ cells $/ \mathrm{ml}$ ) were prepared from the epididymal fat pads of groups of 150 - to $600-\mathrm{g}$ rats, preincubated for $30 \mathrm{~min}$ at $37^{\circ} \mathrm{C}$ in $0.40 \mathrm{ml} \mathrm{KRB}$ buffer containing $10 \mathrm{mg} \mathrm{BSA} / \mathrm{ml}$ and 0 or $100 \mu \mathrm{U}$ insulin $/ \mathrm{ml}$, and incubated for $0.75-2.75 \mathrm{~min}$ in the presence of $1.0 \mathrm{mM} \mathrm{L}-\left[1-{ }^{14} \mathrm{C}\right]$ arabinose $(250 \mu \mathrm{Ci} / \mathrm{mmol})$ and $\mathrm{L}-\left[1-{ }^{3} \mathrm{H}\right]$ glucose $(2.5 \mathrm{mCi} / \mathrm{mmol})$. B and $\mathrm{D}$ : isolated cells $\left(130-610 \times 10^{3}\right.$ cells $\left./ \mathrm{ml}\right)$ were prepared from the epididymal fat pads of groups of $150-$ to $800-\mathrm{g}$ rats and incubated for $60 \mathrm{~min}$ at $37^{\circ} \mathrm{C}$ in $1.5 \mathrm{ml} \mathrm{KRB}$ buffer containing $30 \mathrm{mg}$ $\mathrm{BSA} / \mathrm{ml}, 0.56 \mathrm{mM}\left[1-{ }^{14} \mathrm{C}\right] \mathrm{glucose}(150 \mu \mathrm{Ci} / \mathrm{mmol})$, and 0 or $100 \mu \mathrm{U}$ insulin $/ \mathrm{ml}$. Results are the individual means of triplicate samples obtained in each of the cell preparations studied. 


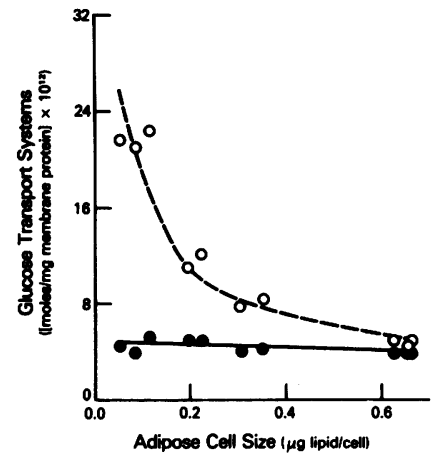

Figure 3 Relationship between the basal ( $)$ and insulinstimulated $(O)$ concentrations of glucose transport systems in the plasma membrane fraction, and adipose cell size. Isolated cells were prepared from the epididymal fat pads of groups of 150 - to $800-\mathrm{g}$ rats, and incubated for $30 \mathrm{~min}$ at $37^{\circ} \mathrm{C}$ in $12 \mathrm{ml} \mathrm{KRB-Hepes} \mathrm{buffer} \mathrm{containing} 10 \mathrm{mg} \mathrm{BSA} / \mathrm{ml}$ and 0 or $1,000 \mu \mathrm{U}$ insulin $/ \mathrm{ml}$. The plasma membrane fraction was then prepared and the concentration of glucose transport systems determined as described in Methods. Results are the individual values obtained in each of the cell preparations studied.

small and large adipose cells (fourth series of experiments) are illustrated in Fig. 4. As previously demonstrated in Fig. 3, cellular enlargement is accompanied by an unchanged number of glucose transport systems/milligram of membrane protein in the plasma membrane fraction in the basal state, but a markedly reduced number/milligram of membrane protein in the maximally insulin-stimulated state (Fig. 4 A). Indeed, in the very large cells examined in this series of experiments, the response to insulin was virtually undetectable.

The high density microsomal membrane fraction prepared from small adipose cells contains few glucose transport systems/milligram of membrane protein in the basal state, and only somewhat more in the insulin-stimulated state (Fig. $4 \mathrm{~B}$ ), probably reflecting the contamination of this microsomal membrane fraction with plasma membranes. ${ }^{2}$ The number of glucose transport systems/milligram of membrane protein in the high density microsomal membrane fraction is influenced little, if any, by increased cell size. In contrast, the low density microsomal membrane fraction prepared from small cells is markedly enriched in glucose transport systems/milligram of membrane protein in the basal state, and incubation of the intact cells in the presence of a maximally stimulating concentration of insulin before homogenization reduces their number/milligram of membrane protein by 50 $60 \%$ (Fig. 4 C). Furthermore, cellular enlargement is accompanied by a marked reduction in the number

\footnotetext{
${ }^{2}$ Unpublished observation.
}

of glucose transport systems/milligram of membrane protein in this membrane fraction in the basal state and by a virtual elimination of the response to insulin. Indeed, among the three membrane fractions prepared from the very large cells examined here, the number of glucose transport systems/milligram of membrane protein is roughly constant, regardless of the basal or insulin-stimulated state.

The relative enrichments and total recoveries of various marker enzyme activities among these same plasma, high density microsomal, and low density microsomal membrane fractions prepared from small and large adipose cells are illustrated in Tables I and II, respectively. The marker enzyme activities measured include 5 '-nucleotidase and isoproterenol-stimulated adenylate cyclase, characteristic of plasma membranes; rotenone-insensitive $\mathrm{NADH}$-cytochrome $c$ reductase and glucose-6-phosphate phosphatase, characteristic of membranes of the endoplasmic reticulum; and UDPgalactose: $N$-acetylglucosamine galactosyltransferase, characteristic primarily of membranes of the Golgi apparatus (43). Increased cell size is accompanied by markedly decreased 5 '-nucleotidase, adenylate cyclase, and galactosyltransferase specific activities; moderately decreased glucose-6-phosphate phosphatase specific activities; and slightly increased NADH-cytochrome $c$ reductase specific activities (Table I). Because these alterations are con-
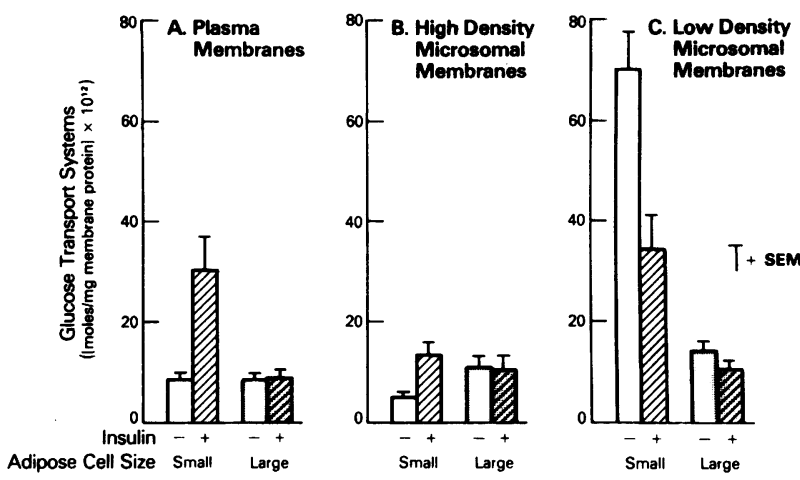

FIGURE 4 Relationship between the basal and insulin-stimulated concentrations of glucose transport systems in the plasma membrane (A), high density microsomal membrane (B), and low density microsomal membrane (C) fractions from small and large adipose cells (mean cells sizes of 0.080 and $0.935 \mu \mathrm{g} \mathrm{lipid/cell,} \mathrm{respectively).} \mathrm{Isolated} \mathrm{cells} \mathrm{were}$ prepared from the epididymal fat pads of groups of 180 and $800-\mathrm{g}$ rats, and incubated for $30 \mathrm{~min}$ at $37^{\circ} \mathrm{C}$ in $36 \mathrm{ml}$ KRB-Hepes buffer containing $10 \mathrm{mg} \mathrm{BSA} / \mathrm{ml}$ and 0 or 1,000 $\mu \mathrm{U}$ insulin $/ \mathrm{ml}$. The plasma, high density microsomal, and low density microsomal membrane fractions were then prepared and the concentrations of glucose transport systems determined as described in Methods. Results are the means \pm SEM of the individual values obtained in each of the three small and four large cell preparations studied. 
TABLE I

Relative Marker Enzyme Specific Activities among Membrane Fractions from Small and Large Adipose Cells

\begin{tabular}{|c|c|c|c|c|}
\hline \multirow[b]{2}{*}{ Marker enzyme activity } & \multirow[b]{2}{*}{$\begin{array}{l}\text { Adipose } \\
\text { cell size }\end{array}$} & \multicolumn{3}{|c|}{ Membrane fraction } \\
\hline & & Plasma membranes & $\begin{array}{l}\text { High density } \\
\text { microsomal membranes }\end{array}$ & $\begin{array}{c}\text { Low density } \\
\text { microsomal membranes }\end{array}$ \\
\hline \multirow{3}{*}{$5^{\prime}$-nucleotidase $(\mu \mathrm{mol} / \mathrm{mg} / \mathrm{h})$} & & \multicolumn{3}{|c|}{$(\% \pm$ SEM) } \\
\hline & Small & $100(1.82 \pm 0.44)^{\circ}$ & $29 \pm 4$ & $5 \pm 0$ \\
\hline & Large & $100(0.30 \pm 0.07)^{\circ}$ & $29 \pm 9$ & $10 \pm 6$ \\
\hline \multirow{2}{*}{$\begin{array}{l}\text { Isoproterenol-stimulated adenylate cyclase } \\
\qquad(\mathrm{nmol} / \mathrm{mg} / 10 \mathrm{~min})\end{array}$} & Small & $100(13.8 \pm 1.4)^{\circ}$ & $27 \pm 4$ & $10 \pm 1$ \\
\hline & Large & $100(4.5 \pm 0.8)^{\circ}$ & $40 \pm 8$ & $10 \pm 3$ \\
\hline \multirow{2}{*}{$\begin{array}{l}\text { Rotenone-insensitive } \mathrm{NADH} \text {-cytochrome } \\
\quad c \text { reductase }(\mu \mathrm{mol} / \mathrm{mg} / \mathrm{min})\end{array}$} & Small & $30 \pm 4 \ddagger$ & $100(1.66 \pm 0.12)^{\circ}$ & $70 \pm 1 \ddagger$ \\
\hline & Large & $17 \pm 2 \ddagger$ & $100(2.12 \pm 0.20)^{\circ}$ & $101 \pm 8 \ddagger$ \\
\hline \multirow{2}{*}{$\begin{array}{l}\text { Glucose-6-phosphate phosphatase } \\
\qquad(\mathrm{nmol} / \mathrm{mg} / \mathrm{h})\end{array}$} & Small & $41 \pm 5$ & $100(1.70 \pm 0.23)^{\circ}$ & $53 \pm 15$ \\
\hline & Large & $34 \pm 2$ & $100(1.09 \pm 0.07)^{\circ}$ & $83 \pm 12$ \\
\hline \multirow{2}{*}{$\begin{array}{l}\text { UDPgalactose: } N \text {-acetylglucosamine } \\
\text { galactosyltransferase }(\mathrm{nmol} / \mathrm{mg} / 2 \mathrm{~h})\end{array}$} & Small & $23 \pm 12$ & $62 \pm 8$ & $100(148 \pm 6)^{\bullet}$ \\
\hline & Large & $34 \pm 7$ & $43 \pm 4$ & $100(57 \pm 5)^{\circ}$ \\
\hline
\end{tabular}

Marker enzyme activities were measured in the membrane fractions prepared in the experiments described in Fig. 4 using the procedures described in Methods. Within each experiment, marker enzyme specific activities were obtained for each membrane fraction prepared from basal and insulin-stimulated cells, the activities obtained for the basal and insulin-stimulated cells averaged, and the average activities expressed as a percentage of their respective highest average activity observed. Results are the means \pm SEM of the individual values obtained in each of the three small and four large cell preparations studied. Mean cell sizes were 0.080 and $0.935 \mu \mathrm{g}$ lipid/cell (small and large, respectively).

- Actual specific activity value set at $100 \%$ (mean \pm SEM).

† Difference between small and large cells is statistically significant at the $P \leq 0.05$ level.

sistent among all three membrane fractions and the original homogenates, however, the relative enrichments and total recoveries of these marker enzyme activities are expressed as percents. With the exception of small differences in NADH-cytochrome $c$ reductase, increased cell size is not accompanied by significant alterations in either the relative enrichments (Table I) or total recoveries (Table II) of the five marker enzyme activities examined here. Indeed, the total yield of membrane protein per cell in each membrane fraction, as well as the yield of total protein per cell in the original homogenate, is roughly proportional to the surface area of the intact cells from which these fractions are prepared (Table III).

\section{DISCUSSION}

Although the "insulin resistance" of the enlarged adipose cell in the aging rat model of obesity is well established (3-18), the mechanisms responsible are not fully understood. A marked decrease in the enlarged cell's maximal capacity for glucose metabolism has previously been reported that appears to dissociate metabolism from transport in the presence of physiological glucose concentrations $(10,15-18)$. Because insulin enhances metabolism primarily through its stimulatory effect on transport, a dissociation of the former from the latter could explain, at least in part, the enlarged cell's insulin resistant glucose metabolism under in vitro conditions that are thought to be physiological. Nevertheless, the present investigations $(a)$ demonstrate that increasing cell size is accompanied by the progressive development of a marked resistance to insulin at the glucose transport level, and $(b)$ suggest that this insulin resistant glucose transport activity can be explained by a marked decrease in the number of glucose transport systems appearing in the plasma membrane in response to insulin, perhaps as the consequence of a relative depletion of glucose transport systems in the cell's intracellular pool. A similar explanation has recently been proposed for the insulin resistant glucose transport of the adipose cell from the streptozotocin-induced diabetic and high fat/low carbohydrate-fed rat $(44,45)$. In addition, in the presence of the low concentration of glucose $(0.56 \mathrm{mM})$ examined here, the enlarged cell's insulin resistance at the glucose transport level is directly reflected in a reduction in insulin's stimulatory effect on glucose metabolism. Because the glucose concentration in the interstitial fluid is unknown, the relative roles of a decreased maximal metabolic capacity and a reduced stimulation of glucose transport by insulin in the in- 
TABLE II

Recovery of Marker Enzyme Activities from Small and Large Adipose Cells

\begin{tabular}{|c|c|c|c|c|}
\hline \multirow[b]{2}{*}{ Marker enzyme activity } & \multirow[b]{2}{*}{$\begin{array}{l}\text { Adipose } \\
\text { cell size }\end{array}$} & \multicolumn{3}{|c|}{ Membrane fraction } \\
\hline & & Plasma membranes & $\begin{array}{l}\text { High density } \\
\text { microsomal membranes }\end{array}$ & $\begin{array}{c}\text { Low density } \\
\text { microsomal membranes }\end{array}$ \\
\hline & & & $(\% \pm S E M)$ & \\
\hline \multirow[t]{2}{*}{ 5'-nucleotidase } & Small & $29.2 \pm 8.1$ & $3.6 \pm 1.1$ & $0.9 \pm 0.1$ \\
\hline & Large & $19.3 \pm 3.3$ & $2.4 \pm 0.7$ & $0.7 \pm 0.4$ \\
\hline \multirow{2}{*}{$\begin{array}{l}\text { Isoproterenol-stimulated adenylate } \\
\text { cyclase }\end{array}$} & Small & $81.5 \pm 20.6$ & $9.9 \pm 3.2$ & $5.1 \pm 1.5$ \\
\hline & Large & $91.4 \pm 12.7$ & $14.5 \pm 3.8$ & $5.4 \pm 2.2$ \\
\hline \multirow{2}{*}{$\begin{array}{l}\text { Rotenone-insensitive NADH-cytochrome } \\
c \text { reductase }\end{array}$} & Small & $8.8 \pm 2.7$ & $12.6 \pm 3.0$ & $12.4 \pm 1.6^{\circ}$ \\
\hline & Large & $7.3 \pm 1.4$ & $14.9 \pm 0.5$ & $21.0 \pm 2.1^{\circ}$ \\
\hline \multirow[t]{2}{*}{ Glucose-6-phosphate phosphatase } & Small & $18.2 \pm 8.4$ & $20.4 \pm 7.1$ & $16.4 \pm 6.3$ \\
\hline & Large & $14.0 \pm 0.6$ & $18.6 \pm 1.6$ & $20.2 \pm 2.9$ \\
\hline \multirow{2}{*}{$\begin{array}{l}\text { UDPgalactose: } N \text {-acetylglucosamine } \\
\text { galactosyltransferase }\end{array}$} & Small & $9.3 \pm 4.5$ & $12.9 \pm 2.8$ & $33.5 \pm 11.1$ \\
\hline & Large & $16.7 \pm 1.6$ & $12.6 \pm 1.1$ & $36.2 \pm 5.9$ \\
\hline
\end{tabular}

Marker enzyme activities were measured in the original homogenates and membrane fractions prepared in the experiments described in Fig. 4 using the procedures described in Methods. Within each experiment, total marker enzyme activities were calculated for each homogenate and membrane fraction prepared from basal and insulin-stimulated cells, the activities obtained for the basal and insulin-stimulated cells summed, and the summed activities for the membrane fractions expressed as a percentage of the summed activity for the homogenates. Results are the means \pm SEM of the individual values obtained in each of the three small and four large cell preparations studied. Mean cell sizes were 0.080 and $0.935 \mu \mathrm{g}$ lipid/cell (small and large, respectively). Increased recoveries of isoproterenol-stimulated adenylate cyclase, relative to 5 '-nucleotidase, activity appear to reflect a reduction of the former in the homogenates due to an inhibitor not present in the membrane fractions (48).

- Difference between small and large cells is statistically significant at the $P \leq 0.05$ level.

sulin resistant glucose metabolism of the enlarged cell in vivo remain to be established.

Increasing adipose cell size in the aging rat is accompanied by increasing basal, but unchanging maximally insulin-stimulated, rates of L-arabinose transport when expressed per cell (Figs. $1 \mathrm{~A}$ and B and 2 $A$ and $B)$. These alterations in glucose transport activ- ity are paralleled by similar alterations in glucose metabolism at an extracellular glucose concentration $(0.56 \mathrm{mM})$ where transport is thought to represent the rate limiting step (18-20). However, neither the alterations in glucose transport activity nor glucose metabolism are accompanied by significant changes in the cell's sensitivity to insulin, as reflected in the con-

TABLE III

Recovery of Protein from Small and Large Adipose Cells

\begin{tabular}{lcccc}
\hline & \multicolumn{3}{c}{ Recovered protein ( \pm SEM) } \\
\cline { 2 - 5 } \multicolumn{1}{c}{ Fraction } & \multicolumn{2}{c}{ Small adipose cells } & \multicolumn{2}{c}{ Large adipose cells } \\
\hline & $(p g / c e l l)$ & $\left(f g / \mu^{2}\right)$ & $(p g / c e l l)$ & $\left(f g / \mu^{2}\right)$ \\
Homogenate & $375 \pm 77^{\circ}$ & $38.9 \pm 8.0$ & $1813 \pm 254^{\circ}$ & $36.9 \pm 6.1$ \\
Plasma membrane fraction & $20.1 \pm 5.8^{\circ}$ & $2.09 \pm 0.60$ & $146 \pm 12^{\circ}$ & $2.95 \pm 0.24$ \\
High density microsomal membrane fraction & $9.0 \pm 3.0^{\circ}$ & $0.93 \pm 0.31$ & $66 \pm 12^{\circ}$ & $1.34 \pm 0.24$ \\
Low density microsomal membrane fraction & $12.9 \pm 3.3^{\circ}$ & $1.35 \pm 0.34$ & $67 \pm 7^{\circ}$ & $1.36 \pm 0.17$ \\
\hline
\end{tabular}

Recovery of protein was measured in the experiments described in Fig. 4 using the procedures described in Methods. Three small and four large cell preparations (mean cell sizes of 0.080 and $0.935 \mu \mathrm{g}$ lipid/cell, mean intracellular water spaces of 2.26 and $4.38 \mathrm{pl} /$ cell) were studied.

- Difference between small and large cells is statistically significant at the $P \leq 0.05$ level. 
centrations of insulin producing half-maximal stimulatory effects (Fig. 1). These latter results are consistent with two recent studies that demonstrate that increasing cell size is not accompanied by alterations in the cell's capacity to bind insulin per unit cellular surface area over the physiological range of insulin concentrations $(12,13)$.

When these cellular functions are expressed per unit cellular surface area, however, increasing adipose cell size is accompanied by unchanging basal, but markedly decreasing maximally insulin-stimulated, glucose transport activity and metabolism (Figs. $1 \mathrm{C}$ and D and $2 \mathrm{C}$ and $\mathrm{D})$. These alterations per unit cellular surface area closely correlate with unchanging basal, but markedly decreasing maximally insulin-stimulated, concentrations of glucose transport systems in the purified plasma membranes prepared from these cells (Fig. 3). Because the yield of membrane protein in the plasma membrane fraction is roughly proportional to the estimated surface area of the intact cells before homogenization (Table III), this correlation (a) provides additional strong supportive evidence for the hypothesis that glucose transport in the intact cell is regulated by modulating the concentration of glucose transport systems in the cell's plasma membrane, and (b) establishes glucose transport as a locus of the "insulin resistance" accompanying cellular enlargement. This striking correlation also suggests the appropriateness of expressing plasma membrane functions of the adipose cell on a per unit cellular surface area basis, and the response to insulin as an increment above the basal level of activity.

The decreased ability of insulin to enhance the concentration of glucose transport systems in the plasma membrane fraction prepared from the enlarged adipose cells of aged, obese rats is closely associated with a decreased concentration of glucose transport systems in the low density microsomal membrane fraction in the basal state (Fig. 4). This latter fraction represents the cell's intracellular pool from which glucose transport systems are translocated to the plasma membrane in response to insulin (22-25). These alterations occur in the absence of all but minor changes in the membrane species comprising those fractions examined here or their recovery, as reflected in the relative enrichments (Table I) and recoveries (Table II) of various marker enzyme activities, respectively. The significance of alterations in the specific activities of these marker enzymes (Table I) remains to be determined.

The total number of glucose transport systems in the intact adipose cell cannot presently be measured, as methods are not available for determining their number in the original homogenate and, therefore, the extent of their recovery in each fraction. In the absence of a direct measure, the recovery of marker enzyme activities could, in principle, be used for estimating this number. However, while the glucose transport systems observed in the plasma membrane fraction can be shown to be associated with the plasma membrane and to fractionate along with plasma membrane marker enzyme activities, ${ }^{3}$ the specific membrane species comprising the intracellular pool of glucose transport systems remains to be determined. Indeed, the failure of the subcellular distribution of glucose transport systems (Fig. 4) to parallel that of any of the five marker enzyme activities examined here (Table I), including UDPgalactose: $N$-acetylglucosamine galactosyltransferase, suggests that the intracellular pool may actually comprise either a unique subfraction of the Golgi apparatus or a distinct membrane species. ${ }^{4}$ Thus, an attempt to estimate the number of glucose transport systems in the intracellular pool of, and thereby, the total number of glucose transport systems in, the intact cell, based on the marker enzyme activity recoveries measured here, cannot presently be justified on theoretical grounds.

Nevertheless, if for comparative purposes only, the recoveries of plasma membrane and intracellular glucose transport systems are assumed to parallel the recoveries of 5'-nucleotidase activity in the plasma membrane fraction and UDPgalactose: $N$-acetylglucosamine galactosyltransferase activity in the low density microsomal membrane fraction, respectively, then the estimates illustrated in Table IV are obtained. Because the marker enzyme specific activities (Table I), protein recoveries (Table III), and concentrations of glucose transport systems (Fig. 4) that comprise these estimates are themselves quite variable, especially for the large adipose cells and in the basal state, the apparent differences between small and large cells may not be statistically significant. Thus, regardless of the basal or insulin-stimulated state, a roughly 12 -fold increase in cell size appears to be associated with no more, and probably less, than a threefold increase in the total number of glucose transport systems per cell. In the basal state, however, the number of glucose transport systems per cell in the plasma membrane is markedly increased in the large, compared with the small, cell, whereas that in the intracellular pool remains relatively unchanged. Furthermore, in response to insulin, the number of glucose transport systems per cell in the small cell's plasma membrane increases roughly fourfold and that in the small cell's intracellular pool simultaneously decreases by roughly $50 \%$, whereas those in the large cell's plasma membrane and intracellular pool do not change.

Within the margins of error in these estimates, the

\footnotetext{
${ }^{3}$ Unpublished observation.

${ }^{4}$ Unpublished observation.
} 
TABLE IV

Estimated Numbers of Glucose Transport Systems per Cell in Small and Large Adipose Cells ${ }^{\circ}$

\begin{tabular}{lcccc}
\hline & & \multicolumn{3}{c}{ Cellular site } \\
\cline { 3 - 5 } $\begin{array}{c}\text { Adipose } \\
\text { cell size }\end{array}$ & Insulin & $\begin{array}{c}\text { Plasma } \\
\text { membrane }\end{array}$ & $\begin{array}{c}\text { Intracellular } \\
\text { pool }\end{array}$ & Total \\
\hline & & & $\left(\times 10^{-6}\right)$ & \\
& & & 1.62 & 1.97 \\
Small & + & 0.35 & 0.80 & 2.05 \\
& - & 1.26 & 1.54 & 5.45 \\
Large & + & 3.92 & 1.17 & 5.22 \\
\hline
\end{tabular}

Numbers of glucose transport systems per cell in the plasma membrane and intracellular pool were estimated from the mean concentration of glucose transport systems/milligram of membrane protein (Fig. 4), mean recovered membrane protein (Table III), and mean recovered 5 '-nucleotidase and UDPgalactose: $N$-acetylglucosamine galactosyltransferase activities (Table II) in the plasma and low density microsomal membrane fractions, respectively, prepared in the experiments described in Fig. 4. Mean cell sizes were 0.080 and $0.935 \mu \mathrm{g}$ lipid/cell (small and large, respectively).

- See text for detailed discussion of limitations of estimates.

markedly increased basal, and moderately increased insulin-stimulated, numbers of glucose transport systems per cell in the plasma membrane of the large, compared with the small, adipose cell roughly correspond to the markedly increased basal and moderately, but not statistically significantly, increased insulinstimulated glucose transport activities per cell actually observed (Fig. 2). When the absolute values are compared directly, however, the apparent increases in the numbers of glucose transport systems per cell in the plasma membrane with increased cell size (Table IV) are considerably greater than the actual increases observed in the glucose transport activities per cell (Fig. 2 ). Such a disparity, if confirmed with more precise estimates of the former, would suggest that increased cell size is accompanied by a decrease in the activity of the glucose transport systems, as well as the marked alteration in their subcellular distribution reported here. A similar apparent disparity is observed in the small cell when insulin's stimulatory effects on the concentration of glucose transport systems in the plasma membrane fraction and glucose transport activity in the intact cell are compared (25). ${ }^{5}$

The mechanisms that regulate the basal distribution of glucose transport systems between the adipose cell's plasma membrane and intracellular pool, and the redistribution of glucose transport systems in response to insulin are presently unknown. Nevertheless, re-

\footnotetext{
${ }^{5}$ Unpublished observation
}

gardless of whether the present results are expressed as concentrations per milligram of membrane protein (Fig. 4) or numbers per cell (Table IV), the observed ratio of plasma membrane to intracellular glucose transport systems in the large cells in the basal state resembles that in the small cells in the maximally insulin-stimulated state. This ratio may therefore reflect the attainment of a limiting distribution of glucose transport systems between the plasma membrane and intracellular pool. The present investigations do not indicate the mechanism through which this ratio is achieved with increasing cell size. However, when the results are expressed per cell (Table IV), the large cells actually appear to be locked in an insulin-stimulatedlike state which does not reverse in the absence of added insulin, perhaps as a consequence of the chronic hyperinsulinemia associated with the aging rat model of obesity. Alternatively, when the results are expressed per milligram of membrane protein (Fig. 4), the concentration of glucose transport systems in the plasma membrane of the large cells in the basal state is comparable to that of the small cells in the basal state, and increasing cell size appears to be accompanied by a marked depletion of glucose transport systems in the intracellular pool. Whereas a constant basal concentration of glucose transport systems appears to be maintained in the plasma membrane during the latter's expansion with increasing cell size, the membranes in the subcellular fraction with which the intracellular pool is associated appear to expand in the absence of a concomitant increase in glucose transport systems.

A selective inhibition of net intracellular glucose transport system synthesis with increasing adipose cell size may parallel the well-established decreasing maximal capacity of the enlarging cell for glucose metabolism, especially for de novo fatty acid synthesis (1518). The retention of a relatively intact mechanism of insulin action, on the other hand, is supported by an observed lack of change in the enlarging cell's maximal antilipolytic response to insulin (46). Thus, the alterations in glucose transport and metabolism and their regulation by insulin that accompany cellular enlargement may very well reflect the consequence of normal growth processes that ultimately prevent the cell from expanding its triglyceride stores beyond some maximal volume (47). The relative roles of age and obesity in these alterations of cellular function in the aging rat model of obesity remain, however, to be clarified (13).

\section{ACKNOWLEDGMENTS}

The authors wish to thank Ruth Segal, Mary Jane Zarnowski, Alex J. Franzusoff, Tina M. Wang, and Dena R. Yver for their expert technical assistance during parts of this work.

These investigations were supported in part by grants AM 
13321 and AM 20076 from the National Institute of Arthritis, Diabetes, and Digestive and Kidney Diseases; grant $\mathrm{H} 65332$ from the National Heart, Lung and Blood Institute; and research grants from The Weight Watchers Foundation, The Kroc Foundation, and The Life Insurance Medical Research Fund.

\section{REFERENCES}

1. Salans, L. B., J. L. Knittle, and J. Hirsch. 1968. The role of adipose cell size and adipose tissue insulin insensitivity in the carbohydrate intolerance of human obesity. $J$. Clin. Invest. 47: 153-165.

2. Salans, L. B., G. A. Bray, S. W. Cushman, E. Danforth, Jr., J. A. Glennon, E. S. Horton, and E. A. H. Sims. 1974. Glucose metabolism and the response to insulin by human adipose tissue in spontaneous and experimental obesity: effects of dietary composition and adipose cell size. J. Clin. Invest. 53: 848-856.

3. Zinder, O., R. Arad, and B. Shapiro. 1967. Effect of cell size on the metabolism of isolated fat cells. Isr. J. Med. Sci. 3: 787-791.

4. DiGirolamo, M., and D. Rudman. 1968. Variations in glucose metabolism and sensitivity to insulin of the rat's adipose tissue, in relation to age and body weight. $E n$ docrinology. 82: 1133-1141.

5. Salans, L. B., and J. W. Dougherty. 1971. The effect of insulin upon glucose metabolism by adipose cells of different size: influence of cell lipid and protein content, age and nutritional state. J. Clin. Invest. 50: 1399-1410.

6. DiGirolamo, M., M. D. Howe, J. Esposito, L. Thurman, and J. L. Owens. 1974. Metabolic patterns and insulin responsiveness of enlarging fat cells. J. Lipid Res. 15: 332-338.

7. Livingston, J. N., P. Cuatrecasas, and D. H. Lockwood. 1972. Insulin insensitivity of large fat cells. Science (Wash. DC). 177: 626-628.

8. Lockwood, D. H., J. N. Livingston, and J. M. Armatruda. 1975. The relation of insulin receptors to insulin resistance. Fed. Proc. 34: 1564-1569.

9. Olefsky, J. M., and G. M. Reaven. 1975. The effects of age and obesity on ${ }^{125} \mathrm{I}$-insulin binding to isolated rat adipocytes. Endocrinology. 96: 1486-1498.

10. Olefsky, J. M. 1976. The effects of spontaneous obesity on insulin binding, glucose transport and glucose oxidation of isolated rat adipocytes. J. Clin. Invest. 57: 842851.

11. Olefsky, J. M. 1976. The insulin receptor: its role in insulin resistance of obesity and diabetes. Diabetes. 25: 1154-1165.

12. Foley, J. E., A. L. Laursen, O. Sonne, and J. Gliemann 1981. Insulin binding and hexose transport in rat adipocytes. Relation to cell size. Diabetologia. 19: 234-241.

13. Cushman, S. W., D. Noda, and L. B. Salans. 1981. Adipose cell size-function relationships: insulin binding and degradation. Am. J. Physiol. 240: E166-E174.

14. Livingston, J. N., and D. H. Lockwood. 1974. Direct measurements of sugar uptake in small and large adipocytes from young and adult rats. Biochem. Biophys. Res. Commun. 61: 989-996.

15. Czech, M. P. 1976. Cellular basis of insulin insensitivity in large rat adipocytes. J. Clin. Invest. 57: 1523-1532.

16. Olefsky, J. M. 1977. Mechanisms of decreased insulin responsiveness of large adipocytes. Endocrinology. 100: 1169-1177.

17. Richardson, D. K., and M. P. Czech. 1978. Primary role of decreased fatty acid synthesis in insulin resistance of large rat adipocytes. Am. J. Physiol. 234: E182-E189.

18. Foley, J. E., S. W. Cushman, and L. B. Salans. 1980. Intracellular glucose concentration in small and large rat adipose cells. Am. J. Physiol. 238: E180-E185.

19. Crofford, O. B., and A. E. Renold. 1965. Glucose uptake by incubated rat epididymal adipose tissue. Characteristics of the glucose transport systems and action of insulin. J. Biol. Chem. 240: 3237-3244.

20. Crofford, O. B., and A. E. Renold. 1965. Glucose uptake by incubated rat epididymal adipose tissue. Rate-limiting steps and site of insulin action. J. Biol. Chem. 240: 14-21.

21. Wardzala, L. J., S. W. Cushman, and L. B. Salans. 1978. Mechanism of insulin action on glucose transport in the isolated rat adipose cell. Enhancement of the number of functional transport systems. J. Biol. Chem. 253: 8002-8005

22. Cushman, S. W., and L. J. Wardzala. 1980. Potential mechanism of insulin action on glucose transport in the isolated rat adipose cell. Apparent translocation of intracellular transport systems to the plasma membrane. J. Biol. Chem. 255: 4758-4762.

23. Karnieli, E., M. J. Zarnowski, P. J. Hissin, I. A. Simpson, L. B. Salans, and S. W. Cushman. 1982. Insulin-stimulated translocation of glucose transport systems in the isolated rat adipose cell. Time course, reversal, insulin concentration dependency, and relationship to glucose transport activity. J. Biol. Chem. 256: 4772-4777.

24. Suzuki, K., and T. Kono. 1980. Evidence that insulin causes translocation of glucose transport activity to the plasma membrane from an intracellular storage site. Proc. Natl. Acad. Sci. U.S.A. 77: 2542-2545.

25. Kono, T., K. Suzuki, L. E. Dansey, F. W. Robinson, and T. L. Blevins. 1981. Energy-dependent and protein synthesis-independent recycling of the insulin-sensitive glucose transport mechanism in fat cells. J. Biol. Chem. 256: 6400-6407.

26. Rodbell, M. 1964. Metabolism of isolated fat cells. I. Effects of hormones on glucose metabolism and lipolysis. J. Biol. Chem. 239: 375-380.

27. Cushman, S. W. 1970. Structure-function relationships in the adipose cell. I. Ultrastructure of the isolated adipose cell. J. Cell Biol. 46: 326-341.

28. Hirsch, J., and E. Gallian. 1968. Methods for the determination of adipose cell size in man and animals. J. Lipid Res. 9: 110-119.

29. Cushman, S. W., and L. B. Salans. 1978. Determination of adipose cell size and number in suspensions of isolated rat and human adipose cells. J. Lipid Res. 19: 269-273.

30. Foley, J. E. 1976. L-Arabinose transport in isolated rat adipose cells. Ph.D. Dissertation. Dartmouth College, Hanover, NH.

31. Foley, J. E., S. W. Cushman, and L. B. Salans. 1978 Glucose transport in isolated rat adipocytes with measurements of L-arabinose uptake. Am. J. Physiol. 234: E112-E119.

32. Gliemann, J., K. Østerlind, J. Vinten, and S. Gammeltoft. 1972. A procedure for measurement of distribution spaces in isolated fat cells. Biochim. Biophys. Acta. 286: 1-9.

33. Cushman, S. W., and M. A. Rizack. 1970. Structurefunction relationships in the adipose cell. III. Effects of bovine serum albumin on the metabolism of glucose and the release of nonesterified fatty acids and glycerol by the isolated adipose cell. J. Cell Biol. 46: 354-361.

34. McKeel, D. W., and L. Jarett. 1970. Preparation and 
characterization of a plasma membrane fraction from isolated fat cells. J. Cell Biol. 44: 417-432.

35. Wardzala, L. J. 1979. Identification of the glucose transport system in purified rat adipose cell plasma membranes using a cytochalasin B binding assay: effects of insulin and altered physiological states. Ph.D. Dissertation. Dartmouth College, Hanover, NH.

36. Avruch, J., and D. F. Hoelzl Wallach. 1971. Preparation and properties of plasma membrane and endoplasmic reticulum fragments from isolated rat fat cells. Biochim. Biophys. Acta. 233: 334-347.

37. Salomon, Y., C. Londos, and M. Rodbell. 1974. A highly sensitive adenylate cyclase assay. Anal. Biochem. 58: 541-548.

38. Dallner, G., P. Siekevitz, and G. E. Palade. 1966. Biogenesis of endoplasmic reticulum membranes. II. Synthesis of constitutive microsomal enzymes in developing rat hepatocyte. J. Cell Biol. 30: 97-117.

39. Nordlie, R. C., and R. A. Jorgenson. 1976. Glucose-6phosphatase. In The Enzymes of Biological Membranes. A. Martonsi, editor. Plenum Publishing Corp., New York. 2: 465-491.

40. Fleischer, B. 1974. Isolation and characterization of golgi apparatus and membranes from rat liver. Methods Enzymol. 31: 180-191.

41. Lowry, O. H., N. J. Rosebrough, A. L. Farr, and R. J.
Randall. 1951. Protein measurement with Folin phenol reagent. J. Biol. Chem. 193: 265-275.

42. Peterson, G. L. 1977. A simplification of the protein assay method of Lowry et al. which is more generally applicable. Anal. Biochem. 83: 346-356.

43. Fleischer, S., and L. Packer, eds. 1974. Methods Enzymol. 31: 1-889.

44. Karnieli, E., P. J. Hissin, I. A. Simpson, L. B. Salans, and S. W. Cushman. 1981. A possible mechanism of insulin resistance in the rat adipose cell in streptozotocin-induced diabetes mellitus: depletion of intracellular glucose transport systems. J. Clin. Invest. 68: 811-814.

45. Hissin, P. J., E. Karnieli, I. A. Simpson, L. B. Salans, and S. W. Cushman. 1982. A possible mechanism of insulin resistance in the rat adipose cell with high fat/low carbohydrate feeding: depletion of intracellular glucose transport systems. Diabetes. 31: 589-592.

46. Olefsky, J. M. 1977. Insensitivity of large rat adipocytes to the antilipolytic effects of insulin. J. Lipid Res. 18: 459-464.

47. Faust, I. M., P. R. Johnson, J. S. Stern, and J. Hirsch. 1978. Diet-induced adipocyte number increase in adult rats: a new model of obesity. Am. J. Physiol. 253: E279E286.

48. Ho, R., and E. W. Sutherland. 1975. cAMP-mediated feedback regulation in target cells. Adv. Cyclic Nucleotide Res. 5: 533-548. 